\title{
A model for enhancing employment outcomes through postsecondary education
}

\author{
Jessie C. Green ${ }^{\mathrm{a}, *}$, Dennis S. Cleary ${ }^{\mathrm{a}}$ and Helen I. Cannella-Malone ${ }^{\mathrm{b}}$ \\ ${ }^{\mathrm{a}}$ The Ohio State University, Wexner Medical Center, Columbus, OH, USA \\ ${ }^{\mathrm{b}}$ The Ohio State University, Columbus, OH, USA
}

Revised/Accepted November 2016

\begin{abstract}
.
BACKGROUND: Young adults with intellectual disabilities (ID) are among the poorest of any disability group (Newman et al., 2011). Service gaps and problems include (a) low expectations; (b) a lack of coordination between education, vocational rehabilitation services (VR), and developmental disabilities (DD) agencies; and (c) families and students expressed frustration with the lack of integrated work options available.

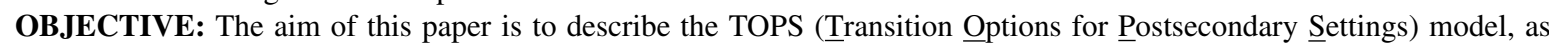
well as provide resources that can be used to support the development and refinement of other postsecondary programs, and, ultimately, improve employment outcomes for individuals with ID.

METHODS: In this paper, we describe how the TOPS program addresses the four transition areas: academic access, career development, campus membership, and self-determination.

CONCLUSIONS: Inclusive postsecondary programs have the potential to improve employment outcomes for people with ID, and using ideas presented in this paper can enhance postsecondary programing.
\end{abstract}

Keywords: Postsecondary program, inclusion, employment, transition, intellectual disability

\section{Introduction}

Findings from the NLTS-2 indicate that postschool outcomes for young adults with intellectual disabilities (ID) are among the poorest of any disability group (Newman et al., 2011). Service gaps and problems include (a) low expectations; (b) a lack of coordination between education, vocational rehabilitation services (VR), and developmental disabilities (DD) agencies; and (c) families and students expressed frustration with the lack of integrated work options. Numerous researchers have identified evidence-based services to improve post-school outcomes for students with ID. For example, students

\footnotetext{
*Address for correspondence: Jessie C. Green, M.Ed., Program Manager, Nisonger Center Transition Services, 257 McCampbell Hall, 1581 Dodd Drive, Columbus, OH 43210, USA. Tel.: +1 614685 3189; Fax: +1 614366 6373; E-mails: jessie.green@osumc.edu; nisonger.osu.edu.
}

with functional cognitive skills (Wagner et al., 2005), high levels of self-determination (Wehmeyer \& Palmer, 2003), and strong academic skills (Benz, Yovanoff, \& Doren, 1997) were more likely to experience post-school success. Since 2010, the Higher Education Opportunity Act (PL 110-315) has supported model demonstration projects that promote the successful transition of students with ID into institutions of higher education through the development of model Comprehensive Transition and Postsecondary Programs (CTP). These programs include degree, certificate, and non-degree programs that support the development of academic skills, employment skills, community membership, and self-determination, with the ultimate goal of improving outcomes for individuals with ID.

With a grant from the US Department of Education (P407A150080), Ohio has established a statewide consortium to extend, enhance, and sustain programs 
Table 1

Resources

\begin{tabular}{|c|c|c|}
\hline Organization & Web Address & Description of Organization \\
\hline Think College & www.thinkcollege.net & $\begin{array}{l}\text { Think College is the national coordinating center for Transition and } \\
\text { Postsecondary Programs for Students with Intellectual } \\
\text { Disabilities (TPSID) }\end{array}$ \\
\hline $\begin{array}{l}\text { Transition Options in Postsecondary Settings } \\
\text { (TOPS) Program }\end{array}$ & www.go.osu.edu/tops & TOPS is a TPSID program at The Ohio State University \\
\hline $\begin{array}{l}\text { National Technical Assistance Center on } \\
\text { Transition (NTACT) }\end{array}$ & www.ntact.org & $\begin{array}{l}\text { NTACT provides technical assistance to a variety of agencies } \\
\text { working towards preparing youth with disabilities for } \\
\text { postsecondary education and employment }\end{array}$ \\
\hline $\begin{array}{l}\text { National Collaborative on Workforce and } \\
\text { Disability/Youth }\end{array}$ & www.ncwd-youth.info & $\begin{array}{l}\text { NCWD-Youth is a resource hub on youth with disability and } \\
\text { employment }\end{array}$ \\
\hline $\begin{array}{l}\text { National Center for Secondary Education } \\
\text { and Training (NCSET) }\end{array}$ & www.ncset.org & $\begin{array}{l}\text { NCSET is a national resource for information on secondary } \\
\text { education and transition for youth with disabilities }\end{array}$ \\
\hline $\begin{array}{l}\text { Association of Higher Education and } \\
\text { Disability (AHEAD) }\end{array}$ & www.ahead.org & $\begin{array}{l}\text { AHEAD is a professional organization of individuals committed to } \\
\text { the full inclusion of persons with disabilities in postsecondary } \\
\text { education }\end{array}$ \\
\hline Disability Benefits 101 (DB101) & www.db101.org & $\begin{array}{l}\text { DB101 provides tools and resources related to employment and } \\
\text { benefits for individuals with disabilities }\end{array}$ \\
\hline
\end{tabular}

that deliver inclusive postsecondary options to students with ID across the state. Ohio's Statewide Consortium (OSC) collaborates with an interdisciplinary team of special educators, rehabilitation counselors, occupational therapists, and parents to provide needed supports to maximize employment and independent living outcomes. Programs in the OSC provide quality academic, employment, and independent living services to students with ID across the state. Given the need to enhance outcomes for individuals with ID, and the emerging evidence suggesting that access to inclusive postsecondary programs is one mechanism that can support improvements, the aim of this paper is to describe the TOPS (Transition Options for Postsecondary Settings) model, which is the foundation model used by the OSC, specifically focusing on the program delivered by The Ohio State University. We also provide resources that can be used to support the development and refinement of other postsecondary programs, and, ultimately, improve employment outcomes for individuals with ID (Table 1).

\section{The TOPS model: Four pillars}

\subsection{Overview}

TOPS embraces the values of community inclusion, cultural diversity, and self-determination, and promotes the pursuit of postsecondary options that include academic enrichment, competitive employment, social engagement, and independent living for individuals with ID. The inclusive individual support model, as described by Hart, Grigal, Sax, Martinez, and Will (2006), most closely aligns with the structure of the TOPS model. Students enrolled in the TOPS program complete either a 2- or 4-year program. Students in the 4-year track complete a minimum of 120 semester hours (an average of 30 semester hours annually) across the four transition areas or pillars (i.e., academics, employment, independent living and campus membership, self-determination) to receive a Generalized Studies Certificate. Students who complete the 2-year track complete a minimum of 60 semester hours across the four transition areas to receive a Certificate of Completion. In the following sections, the manner in which TOPS addresses each of these four pillars is described.

\subsection{Pillar one: Academic access}

Although none of the postsecondary programs in the OSC are degree granting, each program firmly believes that access to academic coursework is an essential part of the college experience, and each provides significant access. Although preliminary, research suggests that including students with ID in college classes benefits both the students with ID and their peers without disabilities (e.g., May, 2012).

At OSU, there are 15 weeks of instructional time in each semester, and the TOPS model follows the academic calendar at each institution. Moreover, students register using the Student Information System (SIS), which is used by regularly enrolled students for inclusive regular university courses and experiences. "Inclusive regular courses" (or "audit courses") are courses that are offered in the course catalog 
and are taught by university faculty members or appointed graduate teaching assistants. These courses are offered at the OSU Columbus campus or can be taken online. TOPS staff use a person centered planning model to work with TOPS students to identify courses that fit the student's general and employment interests. For example, a student interested in history might choose to audit a World War II history course. All programs in the OSC have worked closely with their institutions to (a) identify courses that are preapproved as audit courses, and (b) develop procedures to gain faculty approval to include a TOPS student in a course not on the pre-approved list.

In addition to access inclusive academic courses, TOPS students also enroll in "program courses," which are TOPS learning communities not offered in the course catalog. These learning communities are led by program staff or designated graduate students who are supervised by a faculty member and/or TOPS program staff. TOPS students audit two OSU courses each semester that have a total value equivalent to 4 credit hours. They may also choose to enroll in credit-bearing courses at the local community college. For the OSU audit courses, students will not receive college credit or grades; instead, students earn TOPS program credit toward the Generalized Studies Certificate in both audit and program courses and activities based on achievement of semester goals. The sequence of courses TOPS students can select will lead to a body of knowledge that will be marketable and result in realistic career or education outcomes for each student. Regularly enrolled OSU students register for internship hours to support TOPS students and earn one to three credits toward a minor in Disability Studies or service learning.

\subsection{Pillar two: Career development}

An internship is the first step many college students take as they move into the work force-and this should be the same first step for college students who have ID. Students with ID who participated in a formal internship program have better longterm employment outcomes than students with ID who do not go through a formal internship program (Christensen et al., 2015).

Students in the TOPS program progress through a series of internships that provide opportunities to develop the employment skills they need to find and keep a job they want in a career field they choose. The college campus is ideally suited to host internships for students with ID because colleges provide a wide variety of services to students. Colleges employ staff and faculty members who provide academic, social, and service opportunities; dining and housing; and athletics and recreational activities - all of which provide numerous opportunities for internships.

The TOPS program has taken advantage of many of the opportunities that our large university $(58,000$ students and 30,000 employees) has to offer. It is difficult to think of a career path that does not have some internship potential at a university. TOPS students have participated in internships in athletics, academics, medical settings, horticulture, clerical settings, arts, culinary services, and even the marching band. Students move through various internships to explore their interests and to learn what they like and what they do not like about a particular internship and field. Students typically have at least two internships per year as they advance towards their career goal.

The TOPS program employs job coaches and job developers to help the student explore their interests, interview with potential internship supervisors, and supports the student as they learn the internship duties. Job coaches help the student learn the job and then fade to help ensure that the staff members at the internship site provide natural supports to the individual so that the intern does not become dependent on the job coach (Gilson \& Carter, 2016). There are occasions when a student will be at an internship that they find they do not like-and the job coach helps the student accept the lessons from the internship they can learn in a less than ideal situation. The majority of the time, using the Vocational Fit Assessment (Vocfit.com), a tool developed at Ohio State, students are able to select an internship that suits them. There are times when a student might intentionally choose a challenging internship to develop skills they know they will need for future success. This series of internships provides real life experience, new learning, and ideally a positive reference for future employment as the student builds their resume throughout the program. Some internships have blossomed into paid employment for TOPS students.

The goal in TOPS is to have students move from internships to student employment to permanent employment, which is a natural progression that many students at the university move through. As students are able to manage increased job demands and responsibility they can move from one tier of support to the next. Paid employment before high school graduation is a good indicator of successful employment after graduation (Test et al., 2009) so it would follow that paid employment before college graduation leads 
to students with IDD to have paid employment after graduation.

\subsection{Pillar three: Campus membership}

There are so many ways to belong as a student at Ohio State. One of those ways is through residential options. Currently, students in TOPS are not able to access university housing. They have instead chosen to live in an apartment complex near campus, which is within walking distance to businesses such as banks, grocery stores, restaurants, and a salon. Students use a shuttle to commute between the complex and the university.

Students are taught about the possibilities to get involved at Ohio State from the moment they set foot on campus for orientations. Ohio State is home to over 1,300 registered student organizations, and TOPS students are encouraged to get involved by joining a student organization that interests them. There are many events occurring each week at OSU. Accessing events at Ohio State requires a BuckID, an identification card provided to all students, faculty, and staff at the university. To support an inclusive environment, all programs in the OSC have worked to gain access to this form of identification for all students with ID participating in postsecondary programs. Students in TOPS have a BuckID and attend many events such as Community Commitment (service day sponsored by OSU), sporting events, Big Free Concert, and many others.

As part of the Disability Studies Minor at Ohio State, traditional OSU students are able to complete an internship with the TOPS program. Each semester there is a cohort of around fifty interns who work in many roles including social coaches, who attend social events with TOPS students. Some of these events are prescheduled as a group; others are set up individually between a TOPS student and a social coach, such as attending clubs and organizations. The social coaches are with TOPS students for a variety of support reasons, including to be a known person and to help support a student be an active member of a group. Throughout the course of the semester, many of our students develop friendships with our interns that expand beyond the walls of the classroom and the academic calendar.

\subsection{Pillar four: Self-determination}

Students create, participate in, and present their own Person Centered Plans (PCP). The PCP includes a current summary of progress, goals, and action steps associated with those goals. Students receive a variety of supports during this process including outlines, ideas, and staff and family support. Students often invite their families and/or other support persons to their meetings. Students typically don't love presenting when they first begin the program, however over time, they become more comfortable and begin to feel empowered to make decisions for themselves.

Self-determination is embedded throughout the other three pillars described above: Academic Access, Career Development, and Campus Membership. Program staff works to be sure that students are provided the tools they need to be successful. This could include training others to support a student, rather than doing something for the student, teaching a student how to use assistive technology or walking a student through a process (e.g., how to call to schedule an appointment).

Students are encouraged to advocate at every turn - several of our students have been Leadership and Education in Neurodevelopmental Disabilities (LEND) trainees with the Nisonger Center. They have learned more about their own disability as well as expanding their knowledge of other disabilities, all while learning to advocate for all with disabilities. Many students in the TOPS program have participated in state-wide activities related to advocacy including Project STIR, Youth Leadership Forum and Advocacy Day for Developmental Disabilities at the Ohio Statehouse.

All TOPS students are required to participate in community service volunteering each semester throughout Central Ohio. Some complete it within their home communities; others complete it at Ohio State sponsored events and even a combination of both. These activities engage TOPS students in outreach activities-many of which provide models of self-determination-which help our students grow in their own self-determination efforts.

\section{Conclusion}

The TOPS model is in its sixth year and has had excellent results. There have been eleven graduates of the program $-91 \%$ of whom are currently employed. The alumni average working twenty-four hours per week for $\$ 9.70$ per hour. Many of the alumni work at the Ohio State University or the Columbus Zoo - two of our employment sponsors - where they are able to receive good benefits and access to a retirement plan. 
And while employment outcomes are an important measure of a transition program, the TOPS students have been active members of the university community. University President Michael Drake mentions about the TOPS program when he talks about creating a university of inclusive excellence. The university student who sits alongside the TOPS student will be the future employer who makes decisions about hiring people with disabilities. The education coach who mentors a TOPS student may be the school occupational therapist of the future who expects the children with ID they treat will go to college. TOPS is about inclusion and raising expectations for students with ID and for the university community and services who support those students. In addition to growing socially, academically, and in self-care and self-advocacy skills, the TOPS alumni have helped the university grow as we learn to better meet the needs of all our student learners.

\section{Conflict of interest}

The authors have no conflict of interest to report.

\section{References}

Benz, M. R., \& Yovanoff, P. (1997). School-to-work components that predict postschool success for students with and without disabilities. Exceptional Children, 63, 151-165.
Christensen, J. J., Hetherington, S., Daston, M., \& Riehle, E. (2015). Longitudinal outcomes of Project SEARCH in upstate New York. Journal of Vocational Rehabilitation, 42, 247-255. doi:10.3233/JVR-150746

Gilson, C., \& Carter, E. (2016). Promoting social interactions and job independence for college students with autism or intellectual disability: A pilot study. Journal of Autism and Developmental Disorders, 46, 3583-3596. doi:10.1007/ s10803-016-2894-2

Hart, D., Grigal, M, Sax, C., Martinez, D., \& Will, M. (2006) Postsecondary Options for Students with Intellectual Disabilities. Research to Practice Brief \#46, Institute for Community Inclusion, University of Massachusetts, Boston.

May, C. (2012). An investigation of attitude change in inclusive college classes including young adults with an intellectual disability. Journal of Policy and Practice in Intellectual Disabilities, 9, 240-246.

Newman, L., Wagner, M., Knokey, A., Marder, C., Nagle, K., Shaver, D., \& ... National Center for Special Education Research (2011). The post-high school outcomes of young adults with disabilities up to 8 years after high school: A report from the National Longitudinal Transition Study-2 (NLTS2). NCSER 2011-3005. National Center for Special Education Research.

Test, D. W., Fowler, C. H., Richter, S. M., White, J., Mazzotti, V., Walker, A. R., \& Kortering, L. (2009). Evidence-based practices in secondary transition. Career Development for Exceptional Individuals, 32, 115-128.

Wagner, M., Newman, L., Cameto, R., \& Levine, P. (2005). Changes over time in the early postschool outcomes of youth with disabilities. A report of findings from the National Longitudinal Transition Study (NLTS) and the National Longitudinal Transition Study-2 (NLTS2). Online Submission.

Wehmeyer, M. L., \& Palmer, S. B. (2003). Adult outcomes for students with cognitive disabilities three-years after high school: The impact of self-determination. Education and Training in Developmental Disabilities, 38, 131-144. 